\title{
Editorial
}

\section{East European Feminisms}

\author{
Sally R Munt ${ }^{1 *}$
}

Published: September 8, 2020

\section{GENERAL INTRODUCTION}

The first problem with offering a special issue like this one on feminisms in East Europe is one of definition. East Europe has often come to be reputationally synonymous with the "Iron Curtain" countries that after World War Two were part of the USSR, the Union of Soviet Socialist Republics, or within its sphere of influence. This is a political definition. The geographical definition is problematic too, because ideas about where 'central Europe' and 'eastern Europe' lie are disputed, for example the descriptor 'Eastern Europe' usually includes the Czech Republic (which is in central Europe) and excludes Greece and Cyprus (which are in fact in the far south-east of Europe geographically, the eastest of the east, and certainly its geographically anomalous given that Cyprus is nearer to the Middle East and Lebanon, Syria, and Turkey than 'Europe'). Religion is another way of dividing territory, and conventionally in this definition East Europe includes all those countries that are primarily associated with Eastern Orthodox Christianity - which for the purposes of this special issue might include the autocephalous church of Southern Cyprus, but in other cultural, historical and ideological ways, does not. This religious denotation is rather odd, because countries such as the former Czechoslovakia and Poland are majority Roman Catholic; most Turkish Cypriots in the North are Sunni Muslims, so in this one small island you can see the contention. Arguably, many countries labelled at times 'East Europe' may now reject that label, especially with the recent rise of ethnic nationalism in so many states. So, any concept like 'East Europe' or 'Eastern European' is of course a geopolitical, and thus historical one that is ideologically disputed and loaded.

Nevertheless, we have themed this issue to be one that highlights East European feminisms; the first section of this issue, which is edited separately by Maria Bucur and Krassimira Daskalova, focusses on historical feminisms in this nebulous and contested region. The second section of this issue, edited by myself, is focussed primarily on the present. When we talk about East Europe it is clear that patterns, affiliations and herstories cross these nation states and intersect and diverge in conceptually and politically interesting ways. We have tried in our special issue to represent something of this diversity, whilst also drawing the reader's attention to the colonial effects of communism that were imposed by Russia for decades from around 1945 until December $26^{\text {th }} 1991$, when the USSR simply voted itself out of existence following years of disintegration due to the rise of the independence movements of the 1980s. ${ }^{1}$ Feminist politics in the global north and west repeatably tends to make invisible the separate intellectual histories that have determined feminist activism in 'the East', and has largely continued to pretend that feminist politics only exists in the first world, principally English-speaking countries, as a western preoccupation.

It is our internationalist objective at Feminist Encounters to challenge such western-centrism and we strongly encourage material that contributes to the disruption of this assumption. What our special issue offers is an analytical snapshot of the range of feminist activity in this region, under political, geographic, cultural and economic gender relations that were significantly different from (and yet distinctively recognisable to) those of us living in the west. One of the shortcomings of a western-centric view of feminism, is that 'othered' feminisms become lumped together and undifferentiated, as has often happened in representations of resistance to hetero-patriarchy in Eastern Europe. Thus, stereotypes proliferate, particularly to women of my generation who were raised on pejorative images of beefy grey spectres wearing headscarves queuing for bread and vodka, a stock cartoon from my youth. Even then though, such caricatures were being challenged through the collaborative efforts of ordinary

\footnotetext{
${ }^{1}$ Or 1989 in the Polish case - but this is about Polish state socialism ending in 1989, not 'the USSR' as an entity, which did not include Poland which was one of the socialist states not actually in the USSR. Thank you to Matilda Mroz for this point.
} 
women; in 1970 my mother went on a tour of 'the Soviet Union' (actually Russia, Ukraine, and Uzbekistan) as part of a $\mathrm{CND}^{2}$ delegation from Huddersfield and other towns to promote nuclear disarmament. The purpose, which was sponsored by pro-Soviet elements of the British Labour Party at that time, was to support global disarmament, collaborative feeling, mutuality and world peace. My Mum came back with many lively tales of life under communism, not least was that she explained with surprise and some pride that all jobs were open to men and women, and that housing and heating were provided by the state enabling women to work, a radical idea to a young girl like me in 1970.

Under the Soviets and other state socialist governments, women were declared 'emancipated' in the 1940s; of course this isn't the same thing as the lived experience of equality, but early socialism did seem to be aware of gender discrimination. Political rhetoric aside, these ideals were often at odds with the cultural assumptions of nation states who continued to perceive and enact traditionally ascribed domesticity for women, and resist the emancipatory aims of The Party. The subsequent fall of communism and the growth of European neoliberalism has had some positive effects on information flow, and facilitated greater mutual understanding between Europeans, east and west. In modern times, tourism and migration inbetween and amongst European states has proliferated, meaning that in the UK it is common to have Czech or Polish friends, and those crude 'soviet' stereotypes are dissolving into historical curiosities. But one thing we must continue to resist is the persistent idea that western feminism can 'save' women living in other cultures, the so-called white knight fallacy, that assumes a uni-directional flow of information, strategy, political energy and wisdom.

The first section of this issue is separately introduced by the co-editors, so I will now turn to the articles in the second section edited by myself.

I was very interested to interview Marina Gržinić, who is a feminist and decolonial philosopher and artist based in Ljublijana, Slovenia, with many years of political activism and analysis behind her. Gržinić is an intersectional theorist, tying together issues of territoriality, queer, and feminist protest that challenge the idea of 'fortress Europe', particularly in its appalling treatment of refugees and asylum seekers. Gržinić points out the contrast between the trope of, and self-belief in European Enlightenment - encapsulated perhaps in Beethoven's Ode to Joy, the anthem of the EU - and the torture and imprisonment of foreign asylum seekers at its watery borders. She cites the work of the South African theoretician Achille Mbembe (2003) on necropolitics, and applies it to current European carceral policies, and also engages with East European scholars on how regimes of whiteness continue to underpin and reinforce our gender normativities. She links the emergence of queer politics in Slovenia with the Punk movement in the 1970s, and ties up fascinating connections between queer, feminist, trans and Marxist challenges to white ethnocentrism, reminding us that feminism must always be intrinsically anti-racist in its cartographies of oppression. In raising the presence in postcommunist Slovenia of the 'Erased' (in Slovenian izbrisani) she draws our attention to mainly people from other former Yugoslav republics living in Slovenia without rights. They are mostly of non-Slovene or mixed ethnicity, and they include a significant number of members of Romani communities. Thus, Gržinić's work demonstrates continued exclusions in the imaginary of 'East European feminisms' and challenges the reader to think more carefully about such classification.

Elżbieta Ostrowska's article on 'Gender in Post-1989 Eastern European Cinema' selects several films made in the early postcommunist period, arguing that they represent a 'transitional' moment for gender norms from soviet communism to neoliberal conventions and new points of encounter between western and eastern feminisms. She argues that the film Ildikó Enyedi's My Twentieth Century (Az én XX. századom, Hungary/GDR/ Cuba, 1989) destabilises normative models of femininity by means of both the narrative content and formal strategies. Dorota Kędzierzawska's Nothing (Nic, Poland, 1998) and Ildikó Szabó's, Child Murders (Gyerekgyilkosságok, Hungary, 1993) denounce its discriminatory politics, especially effective on women that represent marginalised sectors of society. The Garden (Záhrada, Slovakia, France, 1995) directed by Martin Šulík, demonstrates how breaking with the code of realism facilitates the process of 'correction of patriarchy'. Each of these films are 'distuptors' of gendered commonsense, provoking a kind of uncertainty that bodes well for the problematisation of gender through the feminist arguments that followed. Although these films were made in different Eastern European countries and at different times, they presaged a kind of spectatorial distanciation that paralleled the disconnect that many Eastern European women felt, after the collapse of communism and their uncertain future. Ostrowska points out that as their femininity was in a state of flux, an estrangement also characterises these women's relationship to western feminism at the time.

Agnieszka Elzbieta Piotrowska asks us to question 'What Does (a Nasty) Woman Want?' in her video essay and critical commentary. This video essay is the first time we have used a moving visual medium in Feminist Encounters, and it follows on from our creative innovations in our previous issue, Feminist Comics in an International Frame (2020, Volume 4, Issue 1). Piotrowska argues, following Pam Cook (2014) and the work of Catherine Grant (2013 and 2018), that the video essay can produce a 'writerly' experience, echoing Marxist Structuralist theorist

${ }^{2}$ Campaign for Nuclear Disarmament, see more at https:// cnduk.org 
Roland Barthes. In this video essay, edited with Anna Dobrowodzka, are juxtaposed material from three films about female desire - made by women at different historical moments in time, in different countries. These are: The Piano (1993) by Jane Campion, Fuga (2018) by Agnieszka Smoczynska and Portrait of a Lady on Fire (2019) by Celine Sciamma. Piotrowska argues that in the Polish context it is particularly important that these three films about female desire speak to each other, as Poland has been late in acknowledging its links to international feminism. The video essay and the text which accompanies it also evoke the recent Polish Nobel Prize Winner for Literature Olga Tokarczuk and Wislowa Szymborska, the Polish poet who also won the Nobel Prize in 1996. In terms of the films, it is the figure of Alicja, in Agnieszka Smoczynska's film, who is the most radical of the three, despite Poland being the most conservative of the countries that produced the films. The video essay is a playful reflection on female desire, a significant preoccupation of feminist visual theory since the 1970s, Piotrowska adds a significant development in these debates using visual representation from Poland.

In Christiana Karayianni and Anastasia Christou's article on 'Feminisms, Gender and Social Media: Public and Political Performativities Regarding Sexual Harassment in Cyprus' we are purposed to stretching our definition of 'Eastern Europe', although certainly Cyprus is a liminal and contested European space due to its ongoing division and cultural dissonance. In their article, the authors examine power dynamics between discourses of misogyny and feminism as produced in the Cypriot public sphere. Their article focuses on how social media, primarily Facebook, was utilised as both a digital space for feminist resistance, and also a platform for misogyny; they provide two case studies which involve one female and two male members of Parliament. Looking at the use of social media in these specific case studies the authors analyse the ways in which feminisms, gender and social media operate, unfold, are negotiated, shaped and positioned in and through the political performances in the public sphere in Cyprus today. They argue how social media can reinforce the neoliberal agenda of individualism and corporatism, and therefore for the necessity for expanding research on the use of social media for countering discourses of misogyny and abuse by less privileged groups of women.

In the final two essays in this issue we move to the more general submissions, which are from the USA and Canada respectively, and which both focus specifically on the politics of the reproductive female body. Shara Crookston's article on 'Navigating TRAP Laws, Protesters, and Police Presence at a Midwestern Abortion Clinic in the United States' is a case study that helps us better understand how TRAP (Targeted Regulation of Abortion Provider) laws and abortion restrictions affect abortion clinics operating in the United States. Crookston conducted a case study of 11 non-physician staff and volunteers at an abortion clinic in a low-income, Midwestern city. Her findings included the view that participants, the abortion clinic staff, were negotiating troublesome and costly TRAP laws, specifically the process of obtaining a transfer agreement with a local hospital in order to stay open. Staff at these clinics felt safe at the clinic due to their ongoing relationship with local police, despite a recent increase in protester presence, but staff at this case study clinic acknowledged that other clinics experience even worse harassment than they did. Crookston concludes that non-physician experiences should be included when examining the impact of TRAP laws and abortion restrictions if feminist sociologists are able to provide a more nuanced understanding of the complexities of abortion work. These valuable interviews provided by Crookston's respondents provide much needed qualitative data on the experiential evidence of impact of TRAP laws and abortion restrictions, which have significant consequences for various Supreme Court decisions over the years.

In May Friedman, Carla Rice and Emily R. M. Lind's article 'A High-Risk Body for Whom? On Fat, Risk, Recognition and Reclamation in Restorying Reproductive Care through Digital Storytelling', the authors present issues of weight stigma in fertility, reproduction, pregnancy and parenting through a fat reproductive justice lens. This mixed methods research project used interview and video-making methods with women-identified and trans people, as well as interviews with healthcare providers and policymakers to investigate perceptions and operations of weight and other stigma in fertility and pregnancy care. They engage with multimedia/digital stories co-written and co-produced with participants involved. Friedman, Rice and Lind consider the ways in which reproductive risk is typically storied in healthcare and culture, and they analyse multimedia/digital stories made by participantvideo-makers who are able to story reproductive wellbeing differently. The authors examine three major themeson risk, on recognition of weight and other stigma, and on reclamation of bodies - that emerged as critical to these storytellers as they navigated instances of fatphobia in their experiences of reproductive care. The authors argue that just as healthcare practitioners strive to practice evidence-based care, feminist researchers must also put into practice storied care — to believe, respect, and honour fat people's stories of their bodies and lives as fundamental to achieving equity and justice in reproductive healthcare.

We hope that you enjoy reading this issue, and also encourage you to catch up with feminist scholarship in and on Indonesia, China, Korea, and the queer critique of war discourse in the USA, in our excellent book reviews.

Good wishes from Feminist Encounters in these turbulent times.

\section{Sally R Munt \\ Chief Editor, Feminist Encounters \\ August 2020}




\section{REFERENCES}

Cook, P. (2014). Word vs. image: Making Mildred's Kiss (2013), The Audiovisual Essay: Practice and theory of videographic film and moving image studies. Available at: https://reframe.sussex.ac.uk/audiovisualessay/reflections/ intransition-1-3/pam-cook/. (Accessed: 11 August, 2020).

Grant, C. (2013). Deja Viewing?: Videographic experiments in intertextual film studies, Mediascape: UCLA's Journal of Cinema and Media Studies. Available at: http://www.tft.ucla.edu/mediascape/Winter2013_DejaViewing.html. (Accessed: 11 August, 2020).

Grant, C. (2018). Screen Memories: A video essay on Smultronstället / Wild Strawberries. Cinergie - Il Cinema e le altre Arti. Available at: https://cinergie.unibo.it/article/view/7914/8116. (Accessed: 11 August, 2020).

Mbembe, A. (2003). Necropolitics. Translated by Libby Meintjes. Public Culture, 15(1), 11-40. https://muse.jhu.edu/article/39984.

Citation: Munt, S. R. (2020). East European Feminisms. Feminist Encounters: A Journal of Critical Studies in Culture and Politics, 4(2), 22. https://doi.org/10.20897/femenc/8509

Copyright (C) 2020 by Author/s and Licensed by Lectito BV, Netherlands. This is an open access article distributed under the Creative Commons Attribution License which permits unrestricted use, distribution, and reproduction in any medium, provided the original work is properly cited. 